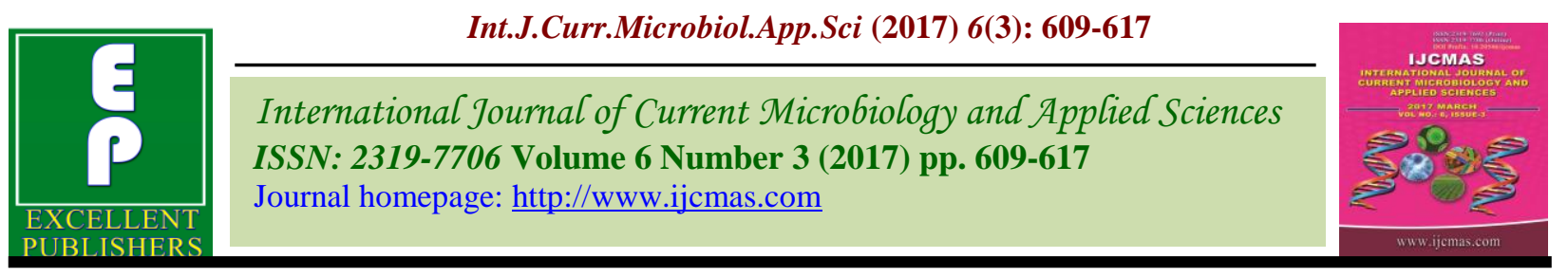

Original Research Article

https://doi.org/10.20546/ijcmas.2017.603.071

\title{
Effect of Different Mulching on Weed Intensity, Yield and Economics in Chilli (Capsicum annuum L.)
}

\author{
V.A. Sathiyamurthy, V. Rajashree, T. Shanmugasundaram* and T. Arumugam \\ Department of Vegetable Crops, HC \& RI, Tamil Nadu Agricultural University, \\ Coimbatore - 641003, Tamil Nadu \\ *Corresponding author
}

\section{A B S T R A C T}

\begin{tabular}{|l|}
\hline Ke y w o r d s \\
Chilli, mulching, \\
organic, polythene, \\
weed density, yield, \\
cost benefit ratio.
\end{tabular}

The use of organic and inorganic mulch as a soil cover is effective in improving growth and yield of chilli (Capsicum annuum L.). A field experiment was carried out at College Orchard, Department of Vegetable Crops, Horticultural College and Research Institute, Tamil Nadu Agricultural University, Coimbatore during 2013 to 2016 to study the effect of different types of mulches viz., organic mulch @ 6.0 t/ha, organic mulch @ $9.0 \mathrm{t} / \mathrm{ha}$, organic mulch @ 12.0 t/ha, black / silver polythene (double coated 30 micron), black / white polythene (double coated 30 micron) with a control on growth and yield of chilli. The experiment was laid out in Randomized Block Design (RBD) with six treatments and replicated four times. The results revealed that organic mulch @ 12.0 t/ha $\left(\mathrm{T}_{4}\right)$ recorded the highest plant height $(88.17 \mathrm{~cm})$, number of fruits/plant $(217.27)$ with an average fruit weight of $4.67 \mathrm{~g}$, fruit length $(8.66 \mathrm{~cm})$, fruit girth $(1.96 \mathrm{~cm})$, green fruit yield $(0.939$ $\mathrm{kg} /$ plant and $325.93 \mathrm{q} / \mathrm{ha})$, dry fruit yield $(0.226 \mathrm{~kg} / \mathrm{plant}$ and $75.98 \mathrm{q} / \mathrm{ha})$ followed by black/white polythene double coated 30 micron $\left(\mathrm{T}_{6}\right)$ which recorded 210.20 number of fruits/plant with an average fruit weight of $4.61 \mathrm{~g}$ and low weed density $\left(13.23 / \mathrm{m}^{2}\right)$ at 75 days after planting with high cost benefit ratio (2.80). Therefore, mulching (organic as well as black/white polythene (double coated 30 micron) appears to be a viable tool to increase the chilli production and recommended for cultivation.

\section{Introduction}

Chilli (Capsicum annuum L.) is cultivated worldwide and is an important spice cum vegetable crop cultivated extensively in India. It is an indispensable spice essentially used in every Indian cuisine for its pungency, taste, colour and aroma. It is rich in proteins, lipids, carbohydrates, fibres, mineral salts $(\mathrm{Ca}, \mathrm{P}, \mathrm{Fe})$ and vitamins like $\mathrm{A}, \mathrm{D}, \mathrm{E}, \mathrm{C}, \mathrm{K}, \mathrm{P}, \mathrm{B} 2$ and B12 with good medicinal properties. The fruits are an excellent source of health-related phytochemical compounds, such as ascorbic acid, carotenoids, tocopherols, flavonoids, and capsaicinoids that are very important in preventing chronic diseases such as cancer, asthma, coughs, sore throats, toothache, diabetes and cardiovascular diseases (ElGhoraba et al., 2013). Thus our country plays a major role in the world chilli market. Keeping the high export potential chilli, production can be increased by a combination of advance production technologies viz., high yielding hybrids, mulching, application of growth regulators, staking, drip fertigation and integrated pest and disease management. Immediately after transplanting, chilli seedlings grow slowly whereas weeds emerge 
fast and grow rapidly competing with the crop severely for growth resources, viz. nutrients, moisture, sunlight and space during entire vegetative and early reproductive stages of chilli (Isik et al., 2009). Further, wide space provided to the chilli allows fast growth of variety of weed species causing a considerable reduction in yield by affecting the growth and yield parameters.

Presence of weeds reduces the photosynthetic efficiency, dry matter production and its distribution to economical parts and there by reduces sink capacity of crop resulting in poor fruit yield. Thus, the extent of reduction in fruit yield of chilli by weeds has been reported to be in the range of $60-70 \%$ depending on the intensity and persistence of weed density in standing crop (Khan et al., 2012). The choice of any weed control measures therefore, depends largely on its effectiveness and economics. Because of increased cost and non-availability of manual labour for hand weeding, herbicides not only control the weeds timely and effectively but also offer a great scope for minimizing the cost of weed control irrespective of situation. Use of pre-emergence herbicide makes the weed control more acceptable to farmers, which will not change the existing agronomic practices but will allow for complete control of weeds.

Mulching is an essential cultural technique that can reduce the amount of work inherent in gardening, helping to produce healthier plants and potentially increasing vegetable yields. Mulch is often defined as any material applied to the soil surface as cover. Organic mulch has a number of positive attributes. It conserves soil moisture by reducing water lost through evaporation, minimizes soil erosion, moderates soil temperatures, inhibits weed growth, encourages the growth of beneficial soil micro-organisms, and reduces the spread of soil-borne pathogens by preventing soil from splashing onto plants during rainstorms and watering. Organic mulches, such as paddy straw, wheat straw, leaf moulds, banana trash, grass, plant waste, sugar cane trash decompose over time, improving soil structure and quality and returning nutrients to the soil. Inorganic mulches are generally used to create barriers to weeds. Inorganic mulch, such as gravel, does not readily decompose. They absorb and reflect heat which can be detrimental during hot, dry weather. Because they do not decompose quickly, inorganic mulches do not improve soil health.

Hence, a study on evaluation of different mulching materials for weed control in transplanted chilli was planned to ascertain the effect of different mulching on weed control and growth and yield of chilli.

\section{Materials and Methods}

The experiment was conducted during three consecutive Kharif seasons of 2013 to 2016 at College Orchard $\left(11.0152^{\circ} \mathrm{N}\right.$ latitude, $76.9326^{\circ} \mathrm{E}$ longitude and $426 \mathrm{~m}$ altitude), Department of Vegetable Crops, HC\&RI, Tamil Nadu Agricultural University, Coimbatore. The experimental soil was well drained and sandy loam in texture, having $\mathrm{pH}$ of 6.92. The experiment was laid out in a randomized block design (RBD) with seven treatments with three replications.

The experimental field was ploughed three times and well decomposed FYM @ 25 t/ha and 75 per cent of recommended dose of fertilizer (RDF) of $\mathrm{P}_{2} \mathrm{O}_{5}(60 \mathrm{~kg} / \mathrm{ha})$ as super phosphate were incorporated uniformly in the last plough and seven raised beds were formed with height of $15 \mathrm{~cm}$, width of $1.20 \mathrm{~m}$ and length of $40 \mathrm{~m}$. The individual bed was earmarked for $12 \mathrm{~m}$ length and a gap of $1 \mathrm{~m}$ was provided between them for assigning treatments and replications. The drip laterals were spread over the beds for irrigation. The treatments consists of 


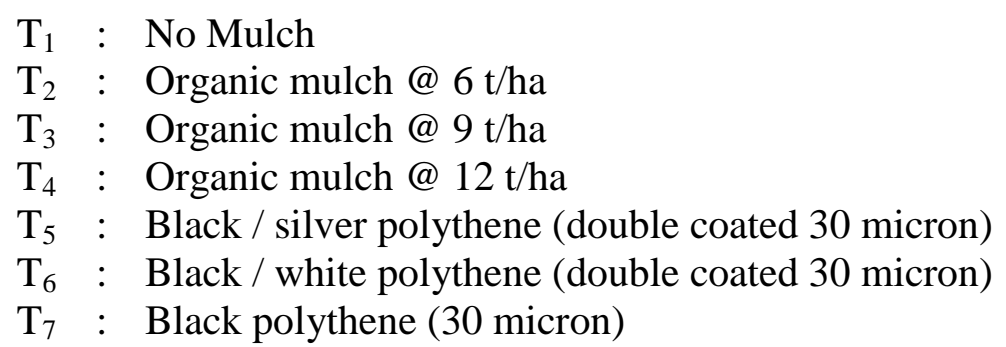

The raised beds assigned for treatments $T_{2}, T_{3}$ and $\mathrm{T}_{4}$ were covered with required quantity of chopped paddy straw and leaf mould. Similarly mulch sheets were spread over the beds for the treatments $T_{5}, T_{6}$ and $T_{7}$. The treatment $\mathrm{T}_{1}$ left as such without any mulch. Thirty five days old Chilli Hybrid "TNAU Chilli hybrid CO 1" seedlings were transplanted in the raised bed with row to row and plant to plant distances of 60 and $50 \mathrm{~cm}$ respectively. The remaining recommended dose of fertilizers (120:20:80 kg NPK/ha) were given as WSF through drip fertigation system uniformly for all the treatments throughout the cropping period. The observation on weed density 75 days after transplanting, fruit length, fruit girth, fruits/plant and yield were recorded. The benefit cost ratio was arrived by using the formula given below.

$$
\begin{aligned}
& \text { Net returns (Rs. ha }{ }^{-1} \text { ) } \\
& \begin{array}{l}
\left.\mathrm{BCR}=\overline{\text { Total cost of expenditure (Rs. ha }}{ }^{-1}\right)
\end{array}
\end{aligned}
$$

Data were subjected to statistical analysis by analysis of variance method (Panse and Sukhatme, 1985). The critical difference was worked out for 5 per cent probability. The results of the experiment was tabulated and presented below.

\section{Results and Discussion}

\section{Influence of mulching on growth character}

The results of the experiment conducted over the three years were pooled and the mean value was presented (Table 1, 2, 3 and 4) and discussed hereunder. The plant height varied significantly due to different types of mulches. Organic mulches showed superior performance in plant height than control, indicating organic mulches had positive effect on the growth and development of chilli. The highest plant height $(88.17 \mathrm{~cm})$ was observed in Organic mulch@12 t/ha $\left(\mathrm{T}_{4}\right)$ followed by organic mulch@9 t/ha $(84.97 \mathrm{~cm})$. The lowest plant height $(71.93 \mathrm{~cm})$ was recorded in control. Application of straw mulch @ 6 t/ha increased yield of tomato and okra by 100 and 200 per cent, respectively over control and marketable fruit yield from mulched plot was significantly higher than those produced on bare soil (Gupta and Gupta, 1987). This difference can be attributed to moisture conservation, higher soil temperature, weed control, and increased mineral nutrient uptake in the mulched plot through improved root temperatures, as reported by Orozco et al., (1994). The increased plant height in mulched plants was possible due to better availability of soil moisture and optimum soil temperature provided by the mulches.

Change in the plant height of chilli was observed by using different mulches and plastic mulch increased the plant height than other mulches. The increase in plant height might be due to reducing water loss through evaporation, minimizes soil erosion, moderates soil temperatures, inhibits weed growth, encourages the growth of beneficial soil microorganisms and reduces the spread of soil-borne pathogens by preventing soil from splashing onto plants during rainstorms and watering. 
Effect of mulching on yield and yield attributes

Among the various treatments, organic mulch @ $12 \mathrm{t} / \mathrm{ha}\left(\mathrm{T}_{4}\right)$ produced more number of fruits per plant and average fruit weight compared to control (Table 1). It meant that mulching had positive influence on fruit setting in chilli. The highest number of fruits per plant (217.27) and average fruit weight (4.67 g) was observed in organic mulch @ 12 t/ha $\left(\mathrm{T}_{4}\right)$ followed by black / white polythene double coated 30 micron $\left(\mathrm{T}_{6}\right)$ (210.20 fruits per plant and $4.61 \mathrm{~g}$ of average fruit weight). In contrast, control $\left(\mathrm{T}_{1}\right)$ recorded the lowest fruits per plant (170.80) and average fruit weight $(4.23 \mathrm{~g})$. The increase in the number of fruits per plant in mulched plot was probably associated with the conservation of moisture and improved micro climate both beneath and above the soil surface. The micro climate condition improved by the mulches might have provided a suitable condition for producing higher number of leaves and fruit bearing nodes in the plant compared to the control.

Considering the relationship between the soil moisture content and fruit number, it was clear that fruit number was strongly related with soil moisture content. Higher soil moisture content and soil temperature under mulch improve the plant microclimate leading to early growth and development, which advances the flowering.

Similar kind of observations with respect to plant growth parameters were also reported by Igbal et al., (2009) in hot pepper, Singh and Kamal (2012) in tomato and Parmar et al., (2013) in watermelon.
These researchers indicated that plants under polyethylene mulch produce larger fruit and have higher fruit yield per plant because of the better plant growth that due to favorable hydro-thermal regime of soil and complete weed free environment. Furthermore, they mentioned that the extended retention of moisture and availability of moisture also lead to a higher uptake of nutrient for proper growth and development of plants, resulted in higher growth of plant as compared to control. Fruit length, fruit diameter and number of seeds per fruit were statistically on par with the other treatments (Table 2) indicating these traits were controlled by genes and not environmentally.

The results revealed that different types of mulching materials (Table 2 and 3) significantly influenced green fruit yield and dry fruit yield over control. Among the different mulching treatments, the treatment $\mathrm{T}_{4}$ - Organic mulch @ $12 \mathrm{t} / \mathrm{ha}$ recorded the highest values for fruit length $(\mathrm{cm})$, fruit girth $(\mathrm{cm})$, green fruit yield $(\mathrm{kg} / \mathrm{plant})$, green fruit yield (q/ha), dry fruit yield $(\mathrm{kg} / \mathrm{plant})$ and dry fruit yield (q/ha) followed by $\mathrm{T}_{6}$.

The increase in the fruit yield was attributed to the sufficient soil moisture in the root zone and minimized evaporation loss due to mulching. The extended retention of moisture and availability of moisture also leads to higher uptake of nutrients for proper growth and development of fruits which resulted in higher yield as compared to the control. Organic mulches return organic matter and plant nutrients to the soil and improve the physical, chemical and biological properties of the soil after decomposition, which in turn increases crop yield. 
Table.1 Effect of different plastic mulches on plant height, number of fruits per plant and average fruit weight of Chilli

\begin{tabular}{|c|c|c|c|c|c|c|c|c|c|c|c|c|}
\hline \multirow{2}{*}{$\begin{array}{l}\text { Treat } \\
\text { ments }\end{array}$} & \multicolumn{4}{|c|}{ Plant height (cm) } & \multicolumn{4}{|c|}{ No.of fruits/ plant } & \multicolumn{4}{|c|}{ Average fruit weight (g) } \\
\hline & 2013-14 & 2014-15 & 2015-16 & Mean & 2013-14 & 2014-15 & 2015-16 & Mean & 2013-14 & 2014-15 & 2015-16 & Mean \\
\hline $\mathrm{T}_{1}$ & 75.7 & 68.9 & 71.2 & 71.93 & 157.1 & 182.0 & 173.3 & 170.80 & 4.19 & 4.23 & 4.28 & 4.23 \\
\hline $\mathrm{T}_{2}$ & 83.5 & 85.6 & 79.3 & 82.80 & 178.3 & 192.4 & 183.2 & 184.63 & 4.21 & 4.60 & 4.63 & 4.48 \\
\hline $\mathrm{T}_{3}$ & 86.5 & 88.3 & 80.1 & 84.97 & 187.7 & 199.8 & 190.3 & 192.60 & 4.57 & 4.50 & 4.55 & 4.54 \\
\hline $\mathrm{T}_{4}$ & 88.0 & 90.3 & 86.2 & 88.17 & 281.8 & 189.5 & 180.5 & 217.27 & 4.58 & 4.50 & 4.92 & 4.67 \\
\hline $\mathrm{T}_{5}$ & 85.0 & 84.3 & 80.2 & 83.17 & 192.1 & 193.2 & 184.0 & 189.77 & 4.69 & 4.60 & 4.58 & 4.62 \\
\hline $\mathrm{T}_{6}$ & 82.0 & 78.9 & 88.3 & 83.07 & 213.6 & 213.6 & 203.4 & 210.20 & 4.53 & 4.64 & 4.66 & 4.61 \\
\hline $\mathrm{T}_{7}$ & 83.8 & 77.3 & 86.6 & 82.57 & 189.7 & 189.7 & 180.7 & 186.70 & 4.52 & 4.52 & 4.59 & 4.54 \\
\hline CD 5\% & 6.46 & 6.39 & 6.34 & 6.3 & 27.54 & 7.45 & 4.75 & 37.04 & 0.056 & 4.23 & $\mathbf{0 . 0 1 3}$ & 0.199 \\
\hline
\end{tabular}

Table.2 Effect of different plastic mulches on fruit length, fruit girth and green fruit yield (kg/plant) of Chilli

\begin{tabular}{|c|c|c|c|c|c|c|c|c|c|c|c|c|}
\hline \multirow{2}{*}{$\begin{array}{l}\text { Treat } \\
\text { ments }\end{array}$} & \multicolumn{4}{|c|}{ Fruit length $(\mathrm{cm})$} & \multicolumn{4}{|c|}{ Fruit girth (cm) } & \multicolumn{4}{|c|}{ Green fruit yield $(\mathrm{kg} /$ plant $)$} \\
\hline & 2013-14 & 2014-15 & 2015-16 & Mean & 2013-14 & 2014-15 & $2015-16$ & Mean & 2013-14 & 2014-15 & $2015-16$ & Mean \\
\hline $\mathrm{T}_{1}$ & 8.33 & 8.30 & 8.36 & 8.33 & 1.80 & 1.68 & 1.64 & 1.71 & 0.743 & 0.728 & 0.728 & 0.733 \\
\hline $\mathrm{T}_{2}$ & 8.59 & 8.48 & 8.42 & 8.50 & 1.90 & 1.87 & 1.67 & 1.81 & 0.853 & 0.836 & 0.885 & 0.858 \\
\hline $\mathrm{T}_{3}$ & 8.71 & 8.59 & 8.46 & 8.59 & 1.90 & 1.95 & 1.85 & 1.90 & 0.895 & 0.877 & 0.854 & 0.875 \\
\hline $\mathrm{T}_{4}$ & 8.91 & 8.65 & 8.41 & 8.66 & 2.00 & 1.98 & 1.90 & 1.96 & 0.928 & 0.909 & 0.979 & 0.939 \\
\hline $\mathrm{T}_{5}$ & 8.62 & 8.53 & 8.53 & 8.56 & 1.90 & 1.91 & 1.86 & 1.89 & 0.861 & 0.844 & 0.879 & 0.861 \\
\hline $\mathrm{T}_{6}$ & 8.37 & 8.36 & 8.66 & 8.46 & 1.82 & 1.78 & 1.92 & 1.84 & 0.825 & 0.809 & 1.021 & 0.885 \\
\hline $\mathrm{T}_{7}$ & 8.35 & 8.42 & 8.45 & 8.41 & 1.80 & 1.85 & 1.85 & 1.83 & 0.832 & 0.816 & 0.875 & 0.841 \\
\hline CD 5\% & NS & NS & 0.013 & NS & NS & NS & 0.009 & NS & 4.25 & 7.62 & 0.013 & 0.073 \\
\hline
\end{tabular}


Table.3 Effect of different plastic mulches on green fruit yield (q/ha), dry fruit yield (kg/plant) and dry fruit yield (q/ha) growth and yield attributes of Chilli

\begin{tabular}{|c|c|c|c|c|c|c|c|c|c|c|c|c|}
\hline \multirow{2}{*}{$\begin{array}{l}\text { Treat } \\
\text { ments }\end{array}$} & \multicolumn{4}{|c|}{ Green fruit yield (q/ha ) } & \multicolumn{4}{|c|}{ Dry fruit yield (kg/plant) } & \multicolumn{4}{|c|}{ Dry fruit yield (q/ha) } \\
\hline & 2013-14 & 2014-15 & $2015-16$ & Mean & 2013-14 & 2014-15 & 2015-16 & Mean & 2013-14 & 2014-15 & $2015-16$ & Mean \\
\hline $\mathrm{T}_{1}$ & 247.8 & 242.8 & 269.63 & 253.41 & 0.144 & 0.155 & 0.154 & 0.151 & 48.0 & 46.5 & 56.5 & 50.33 \\
\hline $\mathrm{T}_{2}$ & 284.4 & 278.7 & 327.78 & 296.96 & 0.174 & 0.183 & 0.229 & 0.195 & 58.0 & 56.8 & 84.73 & 66.51 \\
\hline $\mathrm{T}_{3}$ & 298.3 & 292.3 & 318.29 & 302.96 & 0.187 & 0.202 & 0.220 & 0.203 & 62.3 & 62.5 & 81.40 & 68.73 \\
\hline $\mathrm{T}_{4}$ & 309.2 & 303.0 & 365.59 & 325.93 & 0.203 & 0.225 & 0.249 & 0.226 & 67.7 & 68.1 & 92.13 & 75.98 \\
\hline $\mathrm{T}_{5}$ & 287.0 & 281.3 & 325.50 & 297.93 & 0.164 & 0.162 & 0.247 & 0.191 & 54.7 & 56.9 & 90.62 & 67.41 \\
\hline $\mathrm{T}_{6}$ & 275.0 & 269.5 & 369.37 & 304.62 & 0.163 & 0.166 & 0.260 & 0.196 & 54.3 & 55.8 & 98.2 & 69.43 \\
\hline $\mathrm{T}_{7}$ & 277.4 & 271.9 & 320.82 & 290.04 & 0.168 & 0.174 & 0.235 & 0.192 & 56.0 & 56.2 & 86.3 & 66.17 \\
\hline CD 5\% & 4.25 & 7.62 & 35.06 & 29.20 & 5.75 & 6.89 & 0.0013 & 0.036 & 5.76 & 6.85 & 21.47 & 14.08 \\
\hline
\end{tabular}

Table.4 Effect of different plastic mulches on weed infestation at 75 DAT and Benefit cost ratio of chilli.

\begin{tabular}{|c|c|c|c|c|c|}
\hline \multirow{2}{*}{$\begin{array}{l}\text { Treat } \\
\text { ments }\end{array}$} & \multicolumn{4}{|c|}{$\begin{array}{c}\text { Weed density) / } \mathrm{m}^{2} \\
\text { at } 75 \mathrm{DAT}\end{array}$} & \multirow{2}{*}{$\begin{array}{l}\text { Benefit } \\
\text { cost ratio }\end{array}$} \\
\hline & 2013-14 & 2014-15 & 2015-16 & Mean & \\
\hline $\mathrm{T}_{1}$ & 176 & 176 & 185.5 & 179.17 & 1.25 \\
\hline $\mathrm{T}_{2}$ & 63 & 63 & 75.3 & 67.10 & 1.37 \\
\hline $\mathrm{T}_{3}$ & 51 & 51 & 53.8 & 51.93 & 1.93 \\
\hline $\mathrm{T}_{4}$ & 15 & 14 & 26.0 & 18.33 & 2.05 \\
\hline $\mathrm{T}_{5}$ & 12 & 12 & 23.2 & 15.73 & 1.95 \\
\hline $\mathrm{T}_{6}$ & 13 & 13 & 13.7 & 13.23 & 2.80 \\
\hline $\mathrm{T}_{7}$ & 14 & 14 & 25.0 & 17.67 & 1.29 \\
\hline CD 5\% & 8.12 & 7.20 & 13.09 & 5.56 & - \\
\hline
\end{tabular}


Soil under the mulch remains loose and friable. Aeration and soil microbial activity are enhanced. In heavy black soil also, application of mulches like coir pith @ 20 t/ha, press mud @ 10 t/ha decreased the bulk density over control (Mayalagu, 1983).

The organic mulches not only conserve the soil moisture, they also increase the soil nutrients through organic matter addition (Dilip Kumar et al., 1990). Organic mulches have the advantage of being biodegradable, but decomposition may result in a temporary reduction in soil mineral nitrogen (Wallace and Bellinder, 1992). Similar findings have also been observed by (Dean Ban et al., 2004; Ansary and Roy 2005) in watermelon, (AlMajali and Kasrawi, 1995) in muskmelon, Aruna et al., (2007) in tomato. Plastic mulch reduces evaporation from the soil surface and soil moisture is maintained with greater uniformity. Due to the lack of light under the black plastic mulch, photosynthesis could not be done and weeds cannot grow. Therefore, the plants will have greater access to water and nutrients. In other words, if the mulch is used, less water is consumed and yield can be expected to be higher (Jolaini et al., 2008). The increase in yield per plant might be due to increased uptake of nutrients which resulted in enhanced synthesis of hormones like auxins and gibberellins. Water applied through drip irrigation slowly near to the root zone always maintains soil moisture in field capacity range and no moisture stress occurred during the flowering and fruit development stage and thereby the fruit drop was minimized.

\section{Weed population}

Effect of different mulching treatments (Table 4) significantly influenced the weed density / $\mathrm{m}^{2}$ at 75 days after planting. The common weed species emerged during the experiment was Acalypha indica, Amaranthus viridis,
Trianthema portulacastrum, Portulaca oleraceae, Physalis minima and Cynodon spp. Among the different mulches, black / white polythene double coated 30 micron $\left(\mathrm{T}_{6}\right)$ recorded the lowest weed density $\left(13.23 / \mathrm{m}^{2}\right)$ at 75 days after planting, followed by organic mulch @ 12 t/ha $\left(\mathrm{T}_{4}\right)$. The lowest weed density recorded might be due to the suppression of weeds by increasing the soil temperature resulting in killing the weed seeds in the early stages. The effectiveness of black polythene sheet as mulching material in restricting weed growth has been reported by Chirstopher Lourduraj et al., (1997) in brinjal and Agrawal et al., (2000) in banana. The fact that polythene sheet mulch acts as a barrier between sunlight and soil which further leads to a reduction in the weed growth under the mulches. It might be due to lack of percentage of light through black plastic. Black plastic mulch blocked the weeds, except a few, which emerged through the planting holes (Schonbeck, 1998).

\section{Cost benefit ratio}

The highest cost benefit ratio was recorded in $\mathrm{T}_{6}$ (2.80) followed by $\mathrm{T}_{4}$ (2.05) (Table 4). Even though the yield recorded was slightly higher in $\mathrm{T}_{4}$ compared to $\mathrm{T}_{6}$, the highest cost benefit ratio in $\mathrm{T}_{6}$ was due to the high cost of organic mulch as well the polythene mulch can be used for two seasons.

In conclusion, the results of this study exhibited the significant effect of organic and black /white polythene (double coated 30 micron) plastic mulch on soil moisture content during the growing season. Based on the experimental results, it could be concluded that mulches had tremendous effect on the growth and yield of chilli, showed superior performance in yield. Weed growth was also suppressed by black / white polythene (double coated 30 micron) mulch and thereby, increased the fruit yield with 
high cost benefit ratio. Moreover, using polyethylene plastic mulch produced earlier seedling emergence, more vigorous plant, earlier and higher yield as compared to nonmulched treatment. Therefore, it is recommended to use organics as soil mulching or black / white polythene (double coated 30 micron) to enhance growth and yield of chilli.

\section{References}

Agarwal, N., Agarwal, S.S., Sharma, H.G., Dubey, P. and Dixit, A. 2002. Comparative study of drip vs flood irrigation with and without plastic mulching for banana cv. Dwarf Cavendish. Orissa J. Hort., 30(2): 8084.

Al-Majali, M.A. and Kasrawi, M.A. 1995. Plastic mulch use and method of planting influences on rainfed muskmelon production. Pure \& Appl. Sci., 22(4): 1039-1054.

Ansary, S.H. and Roy, D.C. 2005. Effect of irrigation and mulching on growth, yield and quality of watermelon (Citrullus lanatus Thumb.). Environ. \& Ecol., 23(Spl-1): 141-143.

Aruna, P., Sudagar, I.P., Manivannan, M.I., Rajangam, J. and Natarajan, S. 2007. Effect of fertigation and mulching on yield and quality in tomato cv.PKM-1. Asian J. Hort., 2(2): 0-54.

Chirstopher Lourduraj, A., Padmani, K., Pandiarajan, T. and Sreenarayanan, V.V. 1997. Effect of mulching and irrigation regimes on brinjal (Solanum melongena L.). South Indian J. Hort., 45(5\&6): 228- 234.

Dean Ban Zanic, K., Dumicic, G., Culjak, T.G. and Ban, S.G. 2004. The type of polythene mulch impacts vegetative growth, yield and aphid populations in watermelon production. J. Food. Agric. \& Environ., 7(3-4): 543-550.
Dilip Kumar, G., Sachin S. S., and Rajesh Kumar. 1990. Importance of mulch in crop production. Indian J. Soil Conservation, 18: 20-26.

El-Ghoraba, A.H., Javedb, Q., Anjumb, F.M., Hamedc, S.F., Shaabana, H.A. 2013. Pakistani Bell Pepper (Capsicum annum L.): Chemical Compositions and its Antioxidant Activity. Int. J. Food Properties, 16(1): 18-32.

Gomez, K.A. and Gomez, A.A. 1984. Statistical Procedures for Agricultural Research, 2nd edn. Singapore: John Wiley \& Sons.

Gupta, J.P. and Gupta, G.N. 1987. Response of tomato and okra crops to irrigation and mulch in arid region of India. Agro chemica, 31: 183-202.

Isik, D., Kaya, E., Ngouajio, M. and Mennan, H. 2009. Weed suppression in organic pepper (Capsicum annuum L.) with winter cover crops. Crop Protection, 28: 356-363.

Izakovic, R. 1989. Effect of plastic mulch on the yield and some traits of maize lines. Rostlinna Vyroba, 35: 973-980.

Jolaini, M., Zarei, G.H. and Saffari, A.R. 2008. Effects of moisture regimes and plastic mulching on tomato in subsurface drip irrigation methods. Cera website.

Khan, A., Muhammad, S., Hussain, Z. and Khattak, A.M. 2012. Effect of different weed control methods on weeds and yield of chillies (Capsicum annuum L.). Pak. J. Weed Sci. Res., 18(1): 71-78.

Mayalagu, K. 1983. Influence of different soil amendments on the physical properties of a heavy black soil and yield of groundnut TMV-7 in the Periyar Vaigai command area. Madras Agri. J., 70: 304-308.

Orozco, S.M., Lopez, A.O., Perez, Z.O. and Delgadillo, S.F. 1994. Effect of transparent mulch, floating row cover and oil sprays on insect populations, 
virus diseases and yield of cantaloup. Biol. Agri. Horticulture, 10: 229-234.

Panse, V.G. and P.V. Sukhatme. 1985. Statistical method for agricultural workers, II Edn. ICAR, New Delhi, India.

Rao, K., Subramanyam, K. 2009. Effect of nitrogen fertigation on growth and yield of Pomegranate var. Mridula under low rain fall zone, Agri. Sci. Digest, 29(2): $1-3$.

Ravinder, K., Srivastava, B.K. and Kumer, R. 1997. Effect of different mulch materials on the soil temperature and moisture in winter tomato. Crop Res., 14: $137-141$.

Schonbeck, M.W. 1998. Weed suppression and labor costs associated with organic, plastic, and paper mulches in smallscale vegetable production. J. Sustain. Agric., 13: 13-33.

Wallace, R.W. and Bellinder, R.R. 1992. Alternative tillage and herbicide options for successful weed control in vegetables. Hortsci., 27: 745-749.

\section{How to cite this article:}

Sathiyamurthy, V.A., V. Rajashree, T. Shanmugasundaram and Arumugam, T. 2017. Effect of Different Mulching on Weed Intensity, Yield and Economics in Chilli (Capsicum annuum L.). Int.J.Curr.Microbiol.App.Sci. 6(3): 609-617. doi: https://doi.org/10.20546/ijcmas.2017.603.071 